\title{
Antimicrobial resistance of Escherichia coli isolated from healthy dogs in Lithuania
}

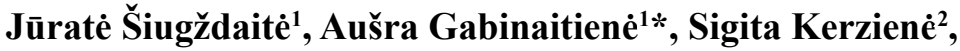 \\ Saulius A. Laurusevičius ${ }^{3}$, and Tomas Laurusevičius ${ }^{3}$

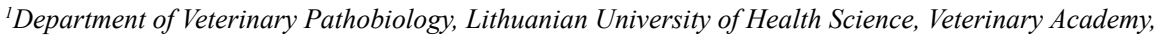 \\ Kaunas, Lithuania \\ ${ }^{2}$ Department of Social Sciences, Lithuanian University of Health Science, Veterinary Academy, \\ Kaunas, Lithuania \\ ${ }^{3}$ Private Veterinary Clinic, Kaunas, Lithuania
}

\section{ŠIUGŽDAITĖ,J..A.GABINAITIENĖ, S. KERZIENĖ, S.A.LAURUSEVIČIUS, T. LAURUSEVIČIIUS: Antimicrobial resistance of Escherichia coli isolated from healthy dogs in Lithuania. Vet. arhiv 88, 355-373, 2018.}

\section{ABSTRACT}

The objective of this study was to establish the prevalence and antimicrobial resistant patterns of commensal Escherichia coli isolated from healthy dogs. In total, 55 rectal swabs from clinically healthy dogs, kept outside $(\mathrm{n}=20)$, and inside a house $(\mathrm{n}=20)$ and from dogs kept at an animal shelter $(\mathrm{n}=15)$, were collected for isolation of Escherichia coli. Resistance patterns to 11 antimicrobial agents were tested using E-test (Epsilometer test) to determine the MIC (Minimum Inhibitory Concentration). Multiplex polymerase chain reaction (M-PCR) amplification was used to detect selected genes conferring resistance to beta-lactams, tetracycline, aminoglycoside, sulphanilamide, quinolone, and phenicol classes of antimicrobial agents. Forty-eight $E$. coli strains were isolated from $55(87.3 \%)$ dogs. Multi-drug resistance was present in $38 \%$ of resistant isolates. E. coli isolates showed the highest resistance rates to streptomycin (85.1\%), ampicillin (77.1\%), sulfamethoxazole (70.8\%) and tetracycline (64.6\%). The isolates were most sensitive to enrofloxacin $(87.5 \%)$ and chloramphenicol $(72.9 \%)$. Bacterial resistance genes were determined to tetracycline (tet) (9.7\%) trimethoprim/sulfamethoxazole (dfrAl) (16.7\%,), and chloramphenicol (catAl) (5.5\%). In general, the prevalence of antimicrobial resistance in $E$. coli isolates from shelter dogs population was higher than in those from dogs kept inside and outside $(\mathrm{P}<0.05)$. Companion animals in Lithuania are important reservoirs of resistant Escherichia coli strains. Only appropriate use of antimicrobials can minimize the spread of resistant bacteria among healthy and diseased animals and humans.

Key words: antimicrobial resistance; commensal E. coli; healthy dogs

\footnotetext{
*Corresponding author:

Dr. Aušra Gabinaitienė, Department of Veterinary Pathobiology, Lithuanian University of Health Science, Veterinary Academy, Tilžès str. 18, LT-47181 Kaunas, Lithuania, E-mail: ausra.gabinaitiene@1smuni.lt
} 


\section{J. Šiugždaitė et al.: Antimicrobial resistance of Escherichia coli}

\section{Introduction}

Bacterial resistance to antibiotics is a world-wide problem in human and veterinary medicine. It is generally accepted that the main risk factor for the increase in the antibiotic resistance is extensive use of antibiotics. In fact, for the last 50 years, high levels of antibiotics have been commonly used for treatment and prevention of infectious diseases in humans and animals. This has led to the emergence and dissemination of resistant bacteria and resistance genes in wild populations (BOUROUNI et al., 2012).

Companion animals, such as dogs, play an important role in the exchanging of antimicrobial resistance determinants in bacterial populations, since they are exposed to antimicrobial agents (for treatment), similar to those used for humans (TAMANG et al., 2012). Through the years, the relationship between companion animals and humans has radically changed, and now cats and dogs are more and more in close contact with humans (MOYAERT et al., 2006). There have been several studies about outbreaks of multi-drug resistant bacterial infection, where a veterinary facility or animal shelter was the only common exposure for infected persons. These studies demonstrate that infected animals brought to veterinary clinics and animal shelters can be foci for nosocomial transmission to other animals, and for zoonotic transmission to humans (DAMBORG et al., 2016).

Escherichia coli (E. coli) are usually a commensal bacterium of humans and animals. Pathogenic variants can cause intestinal and extra intestinal infections, including gastroenteritis, urinary tract infection, meningitis, peritonitis, and septicaemia in both humans and animals (TADESSE et al., 2012). For this reason, faecal E. coli is considered to be a very good indicator for selection pressure in antimicrobial use and expected resistance problems in pathogens (COSTA et al., 2008).

The prevalence of antimicrobial resistance for $E$. coli strains in food producing and companion animals has been documented (SAWANT et al., 2007; AHMED et al., 2010, TADESSE et al., 2012; ÖSTERBERG et al., 2016). Antimicrobial resistant bacteria have been isolated from cattle, pigs, birds, horses, dogs, and cats (GUARDABASSI et al., 2004; MOYAERT et al., 2006; SAWANT et al., 2007; AHMED et al., 2010, LEONARD et al., 2012; TADESSE et al., 2012; ÖSTERBERG et al., 2016, GHOSH et al., 2017). The possibility of transmission of resistant Escherichia coli strains between companion animals and humans has been described (PLATELL et al., 2011). In Lithuania there are studies about antimicrobial resistance in $E$. coli isolates recovered from human clinical samples (POVILONIS et al., 2010) and clinical samples of poultry, calves and pigs (POVILONIS et al., 2010; ŠEPUTIENĖ et al., 2010), but to our knowledge, no study has been carried out on healthy pets.

The objective of this study was to establish the prevalence and antimicrobial resistant patterns of commensal Escherichia coli isolated from healthy dogs. 


\section{J. Šiugždaitė et al.: Antimicrobial resistance of Escherichia coli}

\section{Materials and methods}

Samples collection and bacterial isolation. In this study 55 clinically healthy dogs were investigated according to the requirements of the Law of the Republic of Lithuania on Animal Welfare Regulations (No. B1-866, 2012; Nr. XI-2271, 2012) which was approved by the Lithuanian Committee of Veterinary Medicine and Zootechnics Sciences (Protocol No.09/2012). The rectal swabs were collected by veterinarians using sterile cotton swabs. The swab was inserted approximately $1 \mathrm{~cm}$ into the rectum of pets then placed in Amies transport medium (Amies, Liofilchem, Italy) and stored at $+4{ }^{\circ} \mathrm{C}$ until processing within $24 \mathrm{~h}$.

Forty of the investigated dogs were kept inside or outside a house, and fifteen of the dogs were living in an animal shelter. The rectal samples were collected from clinically healthy dogs of different ages, sexes and breeds (Table 1). None of the investigated animals had taken antimicrobials during the four months prior to the sampling.

Table 1 . The characteristics of the clinically healthy dogs examined

\begin{tabular}{|l|c|c|c|c|c|c|c|c|}
\hline & \multicolumn{5}{|c|}{ Age } & \multicolumn{2}{c|}{ Sex } & \multicolumn{2}{c|}{ Bread } \\
\cline { 2 - 9 } Day time location & $\leq 1$ & $1-5$ & $6-10$ & $\geq 10$ & Male & Female & Purebred & Mixed-breed \\
\hline $\begin{array}{l}\text { Outside the house } \\
(\mathrm{n}=20)\end{array}$ & 1 & 12 & 6 & 1 & 8 & 12 & 15 & 5 \\
\hline $\begin{array}{l}\text { Inside the house } \\
(\mathrm{n}=20)\end{array}$ & 4 & 10 & 4 & 2 & 10 & 10 & 16 & 4 \\
\hline $\begin{array}{l}\text { Animal shelter } \\
(\mathrm{n}=15)\end{array}$ & 2 & 11 & 2 & 0 & 9 & 6 & 6 & 9 \\
\hline
\end{tabular}

Rectal swabs were streaked onto MacConkey's agar (Liofilchem, Italy) and incubated at $+37{ }^{\circ} \mathrm{C}$ for 18 to $24 \mathrm{~h}$. Rose pink colonies were observed after incubation, then a single colony was streaked onto TBX agar (Liofilchem, Italy) and incubated at $+37^{\circ} \mathrm{C}$ for $24 \mathrm{~h}$. The next day blue/green colonies were considered as E. coli and were identified by biochemical testing with an API 20E system (BioMérieux, La Balme Les Grottes, France).

Antimicrobial susceptibility testing. Antimicrobial minimum inhibitory concentrations (MICs) were determined using an E-test system (Epsilometer test) in accordance with the manufacturer's instructions (MIC Test strip, Liofilchem, Italy).

E. coli isolates were sub-cultured onto Nutrient agar (Liofilchem, Italy) and incubated at $+37{ }^{\circ} \mathrm{C}$ temperature for $24 \mathrm{~h}$. The next day at least three colonies of each isolate were selected and re-suspended in Mueller Hinton broth (Liofilchem, Italy) until the 0.5 standard was reached (DEN-1 McFarland Densitometer, Biosan, Latvia). The suspension was swabbed onto Mueller-Hinton agar (Liofilchem, Italy) and the plates were dried in a bio hood at room temperature. Two E-test strips containing a predefined gradient of the antimicrobials were placed on each plate. The E-test strips were placed 


\section{J. Šiugždaitė et al.: Antimicrobial resistance of Escherichia coli}

onto inoculated agar surfaces with the minimum inhibitory concentration (MIC) scales facing upwards. The plates were then incubated in aerobic conditions at $+35 \pm 2{ }^{\circ} \mathrm{C}$ for 18 to $24 \mathrm{~h}$. The MICs were read according to the E-test reading guide: where the edge of the inhibition ellipse intersected the side of the strip (AB Biodisk, Solna, Sweden). Eleven antimicrobial agents were tested in this study: ampicillin, tetracycline, streptomycin, sulfamethoxazole, chloramphenicol, polymyxin B, trimethoprim/sulfamethoxazole, enrofloxacin, nitrofurantoin, gentamicin, and amoxicillin/clavulanic acid (Trek Diagnostic Systems, Cleveland, $\mathrm{OH}$ ). The results of these investigations were used to categorise the isolates as susceptible, intermediate or resistant to antimicrobials, according to the MIC breakpoints reported by the European Committee on Antimicrobial Susceptibility Testing (EUCAST, 2017). Susceptibility to chloramphenicol, polymyxin B and tetracycline was calculated using breakpoints derived from human data, as recommended by the Clinical and Laboratory Standards Institute (CLSI, 2015). A reference strain of E. coli ATCC 25922 was used for quality control for antimicrobial susceptibility testing.

Table 2. Sequences of oligonucleotide primers used in PCR assays for identification of antimicrobial resistance genes in E. coli isolates

\begin{tabular}{|c|c|c|c|c|}
\hline $\begin{array}{l}\text { Antimicrobial } \\
\text { agent }\end{array}$ & $\begin{array}{l}\text { Targe } \\
\text { gene }\end{array}$ & Nucleotide Sequence & $\begin{array}{c}\text { Product } \\
\text { length } \\
\text { (base pairs) }\end{array}$ & Reference \\
\hline \multirow{2}{*}{ Aminoglycoside } & $\operatorname{aadA1}$ & $\begin{array}{l}\text { TATCCAGCTAAGCGCGAACT } \\
\text { ATTTGCCGACTACCTTGGTC }\end{array}$ & \multirow{2}{*}{447} & \multirow{2}{*}{$\begin{array}{l}\text { Van et al., } \\
2008\end{array}$} \\
\hline & $\begin{array}{l}\operatorname{aac}(3)- \\
I V\end{array}$ & $\begin{array}{l}\text { CTTCAGGATGGCAAGTTGGT } \\
\text { TCATCTCGTTCTCCGCTCAT } \\
\end{array}$ & & \\
\hline \multirow{2}{*}{ Tetracycline } & $\operatorname{tet}(A)$ & $\begin{array}{l}\text { GGTTCACTCGAACGACGTCA } \\
\text { CTGTCCGACAAGTTGCATGA }\end{array}$ & 577 & $\begin{array}{l}\text { Randall et } \\
\text { al., } 2004\end{array}$ \\
\hline & $\operatorname{tet}(B)$ & $\begin{array}{l}\text { CCTCAGCTTCTCAACGCGTG } \\
\text { GCACCTTGCTGATGACTCTT }\end{array}$ & 634 & $\begin{array}{l}\text { Randall et } \\
\text { al., } 2004\end{array}$ \\
\hline $\begin{array}{l}\text { Trimethoprim/ } \\
\text { sulfamethoxazole }\end{array}$ & $d f r A l$ & $\begin{array}{l}\text { GGAGTGCCAAAGGTGAACAGC } \\
\text { GAGGCGAAGTCTTGGGTAAAAAC }\end{array}$ & 367 & $\begin{array}{l}\text { Toro et al., } \\
2005\end{array}$ \\
\hline Quinolones & $q n r A$ & $\begin{array}{l}\text { GGGTATGGATATTATTGATAAAG } \\
\text { CTAATCCGGCAGCACTATTTA }\end{array}$ & 670 & $\begin{array}{l}\text { Mammeri et } \\
\text { al., } 2005\end{array}$ \\
\hline Sulphanilamide & sull & $\begin{array}{l}\text { TTCGGCATTCTGAATCTCAC } \\
\text { ATGATCTAACCCTCGGTCTC } \\
\end{array}$ & 822 & $\begin{array}{l}\text { Van et al., } \\
2008\end{array}$ \\
\hline \multirow{2}{*}{ Beta-lactams } & $b l a_{S H V}$ & $\begin{array}{l}\text { TCGCCTGTGTATTATCTCCC } \\
\text { CGCAGATAAATCACCACAATG }\end{array}$ & 768 & $\begin{array}{l}\text { Van et al., } \\
2008\end{array}$ \\
\hline & $b l a_{C M Y}$ & $\begin{array}{l}\text { TGGCCAGAACTGACAGGCAAA } \\
\text { TTTCTCCTGAACGTGGCTGGC }\end{array}$ & 462 & $\begin{array}{l}\text { Van et al., } \\
2008\end{array}$ \\
\hline \multirow{2}{*}{ Phenicol } & catAl & $\begin{array}{l}\text { AGTTGCTCAATGTACCTATAACC } \\
\text { TTGTAATTCATTAAGCATTCTGCC }\end{array}$ & 547 & $\begin{array}{l}\text { Van et al., } \\
2008\end{array}$ \\
\hline & $\mathrm{cmlA}$ & $\begin{array}{l}\text { CCGCCACGGTGTTGTTGTTATC } \\
\text { CACCTTGCCTGCCCATCATTAG }\end{array}$ & 698 & $\begin{array}{l}\text { Van et al., } \\
2008\end{array}$ \\
\hline
\end{tabular}


The isolates were examined for resistance genes using multiplex polymerase chain reaction (M-PGR) according to MOMTAZ et al. (2012). Beta-lactams-resistant isolates were investigated for the presence of blaSHV and blaCMY genes. Tetracycline-resistant isolates were examined for tet $A$ and tet $B$ genes. Strains resistant to trimethoprim/ sulfamethoxazole were investigated for $d$ fr $A 1$. Aminoglycoside-resistant isolates were examined for aadAl and $a a c(3)-I V$ genes. Strains resistant to sulfamethoxazole were investigated for the sull gene, and strains resistant to enrofloxacin - for the qnrA gene. Chloramphenicol-resistant strains were investigated for the catAl and $\mathrm{cmlA}$ genes. The primers used in M-PGR are described in Table 2 (MOMTAZ et al., 2012).

Bacterial DNA from E. coli was extracted with a Chelex 100 (Sigma, USA) according to the manufacturer's instructions. The colony of each E. coli strains from Nutrient agar (Liofilchem, Italy) was picked and placed into a separate sterile Eppendorf tube, containing $200 \mu \mathrm{L}$ of $5 \%$ Chelex solution. The suspension was heated at $+80^{\circ} \mathrm{C}$ for 25 min and boiled at $+95^{\circ} \mathrm{C}$ for $10 \mathrm{~min}$. The heated solution was then centrifuged for $3 \mathrm{~min}$ at $10000 \mathrm{rpm}$. The supernatants were transferred to new sterile Eppendorf tubes and used as template DNA in PCR.

The PCR amplifications were performed in a final volume of $25 \mu \mathrm{L}$ including $10 \times$ PCR buffer (50 mM KCl, 10 mM Tris-HCl (pH 9.0), 0.1\% Triton X-100; MBI, Ferment), $1.5 \mathrm{mM} \mathrm{MgCl}, 200 \mu \mathrm{m}$ of each dNTP (MBI, Fermentas), $1 \mathrm{IU}$ of Taq DNA polymerase (MBI, Ferment), $1 \mu \mathrm{L}$ of each of the oligonucleotides and $5 \mu \mathrm{L}$ of template DNA. The amplifications were performed on a PTC-100 programmable thermal controller (MJ Research Inc., USA) under the following conditions: initial denaturation at $+95^{\circ} \mathrm{C}$ for $3 \mathrm{~min}$, followed by thirty-five cycles of $+94{ }^{\circ} \mathrm{C}$ for $1 \mathrm{~min}, \sim 55{ }^{\circ} \mathrm{C}$ for $90 \mathrm{~s},+72{ }^{\circ} \mathrm{C}$ for $1 \mathrm{~min}$ and a final extension step of $+72^{\circ} \mathrm{C}$ for $10 \mathrm{~min}$. Electrophoresis of PCR products was performed in TAE buffer ( $40 \mathrm{mM}$ Tris, $20 \mathrm{mM}$ acetic acid, $1 \mathrm{mM}$ EDTA), at $100 \mathrm{~V}$ for $60 \mathrm{~min}$. PCR products were analysed in 1\% Top Vision LE GQ Agarose gels (MBI, Fermentas) with $1.5 \%$ ethidium bromide under a UV lamp. The GeneRuler TM $100 \mathrm{bp}$ DNA Ladder (MBI, Fermentas) was used to evaluate the sizes of PCR products. Strains of E. coli ATCC 25922 as the positive control, and sterile distilled water as the negative control were used in the PCR.

Statistical analysis. Descriptive statistical analyses were calculated using the SPSS 13.0 statistical package for Windows (2004). The Chi-squared $(\chi 2)$ test was used to examine the association of the prevalence of $E$. coli with the dogs' age, sex, breed, and housing situation. The Kruskal-Wallis test was used to evaluate the correlation between antimicrobial resistances of $E$. coli with the housing conditions and the ages of the pets. The $\mathrm{P}$ values $\mathrm{P}<0.05, \mathrm{P}<0.01$ and $\mathrm{P}<0.001$ were considered statistically significant. 


\section{Results}

To assess the prevalence of $E$. coli in clinically healthy dogs, 55 faecal samples were investigated. A total of $48 \mathrm{E}$. coli strains were isolated from $55(87.3 \%)$ dogs. Eighteen $(37.5 \%)$ bacterial isolates were retrieved from dogs kept inside a house, 20 (41.7\%) from dogs kept outside, and 10 (20.8\%) - from dogs kept in an animal shelter. The pets' housing situation had a significant influence $(\mathrm{P}<0.01)$ on the occurrence of $E$. coli in the dogs. A higher prevalence of these bacteria was obtained from dogs kept outside a house than from dogs kept inside and in a shelter.

The prevalence of E. coli was found to be higher in female dogs than in male dogs. E. coli more commonly colonized purebred dogs (Table 3 ). Regarding the age of animals, it was found that dogs in the age groups from 1 to 5 years old and 6 to 10 year-old age ranges showed a rather high occurrence of these bacteria, as compared to the age groups of less than one and greater than 10 . However, none of these differences were statistically significant $(\mathrm{P}>0.05)$.

Table 3. The prevalence of $E$. coli at rectum of dogs according to the main dog's characteristic

\begin{tabular}{|c|c|c|c|c|c|c|c|c|c|}
\hline \multirow{3}{*}{$\begin{array}{l}\text { Animal } \\
\text { characteristic }\end{array}$} & \multicolumn{9}{|c|}{ Day time location } \\
\hline & \multicolumn{2}{|c|}{$\begin{array}{l}\text { Outside only } \\
\quad(n=20)\end{array}$} & \multirow[b]{2}{*}{ P-value } & \multicolumn{2}{|c|}{$\begin{array}{l}\text { Inside the } \\
\text { house } \\
(\mathrm{n}=18)\end{array}$} & \multirow[b]{2}{*}{$\mathrm{P}$-value } & \multicolumn{2}{|c|}{$\begin{array}{c}\text { Animal } \\
\text { shelter } \\
(\mathrm{n}=10)\end{array}$} & \multirow[b]{2}{*}{ P-value } \\
\hline & $\mathrm{n}$ & $\%$ & & $\mathrm{n}$ & $\%$ & & $\mathrm{n}$ & $\%$ & \\
\hline \multicolumn{10}{|l|}{ Sex of dogs } \\
\hline Female & 12 & 60 & \multirow{2}{*}{1} & 9 & 50 & \multirow{2}{*}{1} & 7 & 70 & \multirow{2}{*}{0.329} \\
\hline Male & 8 & 40 & & 9 & 50 & & 3 & 30 & \\
\hline \multicolumn{10}{|l|}{ Age of dogs } \\
\hline$\leq 1$ & 1 & 5 & \multirow{4}{*}{1} & 3 & 16.7 & \multirow{4}{*}{0.763} & 1 & 10 & \multirow{4}{*}{0.912} \\
\hline $1-5$ & 12 & 60 & & 9 & 50 & & 7 & 70 & \\
\hline $6-10$ & 6 & 30 & & 4 & 22.2 & & 2 & 20 & \\
\hline$\geq 10$ & 1 & 5 & & 2 & 11.1 & & 0 & 0 & \\
\hline \multicolumn{10}{|l|}{ Bread of dogs } \\
\hline Pure & 16 & 80 & \multirow{2}{*}{0.426} & 14 & 77.8 & \multirow{2}{*}{0.217} & 5 & 50 & \multirow[t]{2}{*}{1} \\
\hline Mixed & 4 & 20 & & 4 & 22.2 & & 5 & 50 & \\
\hline
\end{tabular}

$\mathrm{P}$-value considered statistically significant at $\mathrm{P}<0.05$

The susceptibility of E. coli isolates to eleven antimicrobial agents is shown in Table 4. 
Overall, of the $48 \mathrm{E}$. coli tested by E-test, 24 (49.5\%) isolates were resistant to at least one antimicrobial agent. High resistance rates were observed to streptomycin $(85.1 \%)$, ampicillin (77.1\%), sulfamethoxazole (70.8\%), and tetracycline (64.6\%). Moderate resistance rates were found to nitrofurantoin $(47.9 \%)$, gentamicin and polymyxin B $(41.7 \%$ each), amoxicillin/clavulanic acid (39.6\%), and trimethoprim/sulfamethoxazole (37.5\%). Lower resistance rates were observed for enrofloxacin $(27.1 \%)$ and chloramphenicol (12.5\%). Resistance to ampicillin, amoxicillin/clavulanic acid, streptomycin, gentamicin, trimethoprim/sulfamethoxazole, tetracycline and sulfamethoxazole was the most common combination in the $E$. coli isolates.

Resistance to three or more antimicrobials were observed in $37.5 \%(18 / 48)$ of the $E$. coli tested. E. coli isolates from shelter dogs (70\%) had a significantly higher prevalence of multi-drug resistance to antimicrobial agents than that observed for $E$. coli isolates from dogs kept inside and outside a house $(40 \% ; \mathrm{P}<0.05)$.

Resistance to gentamicin (90\%) and polymyxin B (100\%) was determined more often in the isolates from shelter dogs than in those isolated from dogs kept inside and outside $(\mathrm{P}<0.05)$. Isolates from the population of shelter dogs were more frequently resistant to chloramphenicol (40\%) and enrofloxacin (50\%) than isolates obtained from dogs kept outside $(\mathrm{P}<0.05)$. Isolates from dogs kept outside were more frequently resistant to enrofloxacin $(38.9 \%)$ comparable with isolates from dogs kept inside $(5 \%)(\mathrm{P}<0.05)$. The antimicrobial resistance patterns of the $48 \mathrm{E}$. coli isolates against antimicrobial agents are shown in Table 5.

The age of dogs has a significant influence on the occurrence of E. coli resistance in dogs kept inside and outside a house $(\mathrm{P}<0.05 ; \mathrm{P}<0.01)$. Isolates obtained from 1 to 5 year old dogs kept outside a house and from 5 to 10 year old dogs kept inside were more resistant to streptomycin, chloramphenicol and amoxicillin/clavulanic acid $(\mathrm{P}<0.05)$ than bacteria isolated from the remaining age groups of the same dog populations. Resistance to sulfamethoxazole and enrofloxacin $(\mathrm{P}<0.01)$ was more often determined in bacteria isolated from 5 to 10 year old dogs kept outside a house than in other isolates of E. coli.

A total of 31 tetracycline-resistant $E$. coli isolates were analysed by multiplex PCR for tet $A$ and $t e t B$ gene identification. Ten percent (3/31) of these isolates were positive for tet genes: the tet $A$ gene was detected in $6.4 \%$ and tet $\mathrm{B}$ in $3.2 \%$ of $E$. coli. The catA 1 gene was identified in $16.7 \%(1 / 6)$ of the chloramphenicol-resistant isolates. Only $5.5 \%$ $(1 / 18)$ trimethoprim/sulfamethoxazole-resistant isolate had $d f r A 1$ gene encoding resistant to trimethoprim.

Thirty-seven of the E. coli isolates showed resistance to ampicillin and nineteen to amoxicillin/clavulanic acid. No genes encoding resistance to beta lactams antibiotics (bla $a_{\mathrm{SHV}}$ and $\left.b l a_{\mathrm{CMY}}\right)$ were detected in resistant strains. No genes encoding resistance to aminoglycosides ( $a a c(3)-I V$ and $a a d A 1)$, fluoroquinolone ( $q n r A)$, sulfamethoxazole (sull) and trimethoprim/sulfamethoxazole ( $\mathrm{cmlA}$ ) were detected by PCR in any isolates. 
J. Šiugždaitè et al.: Antimicrobial resistance of Escherichia coli

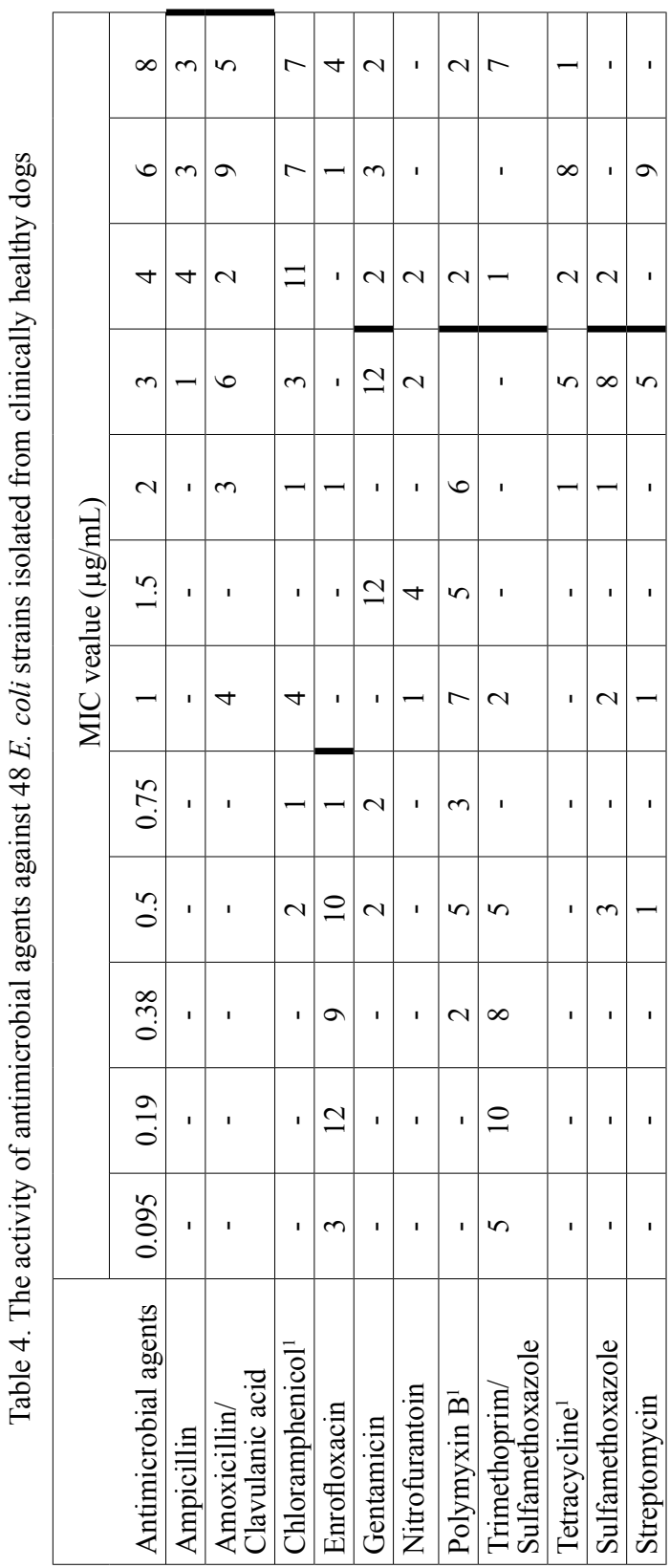


J. Šiugždaitė et al.: Antimicrobial resistance of Escherichia coli

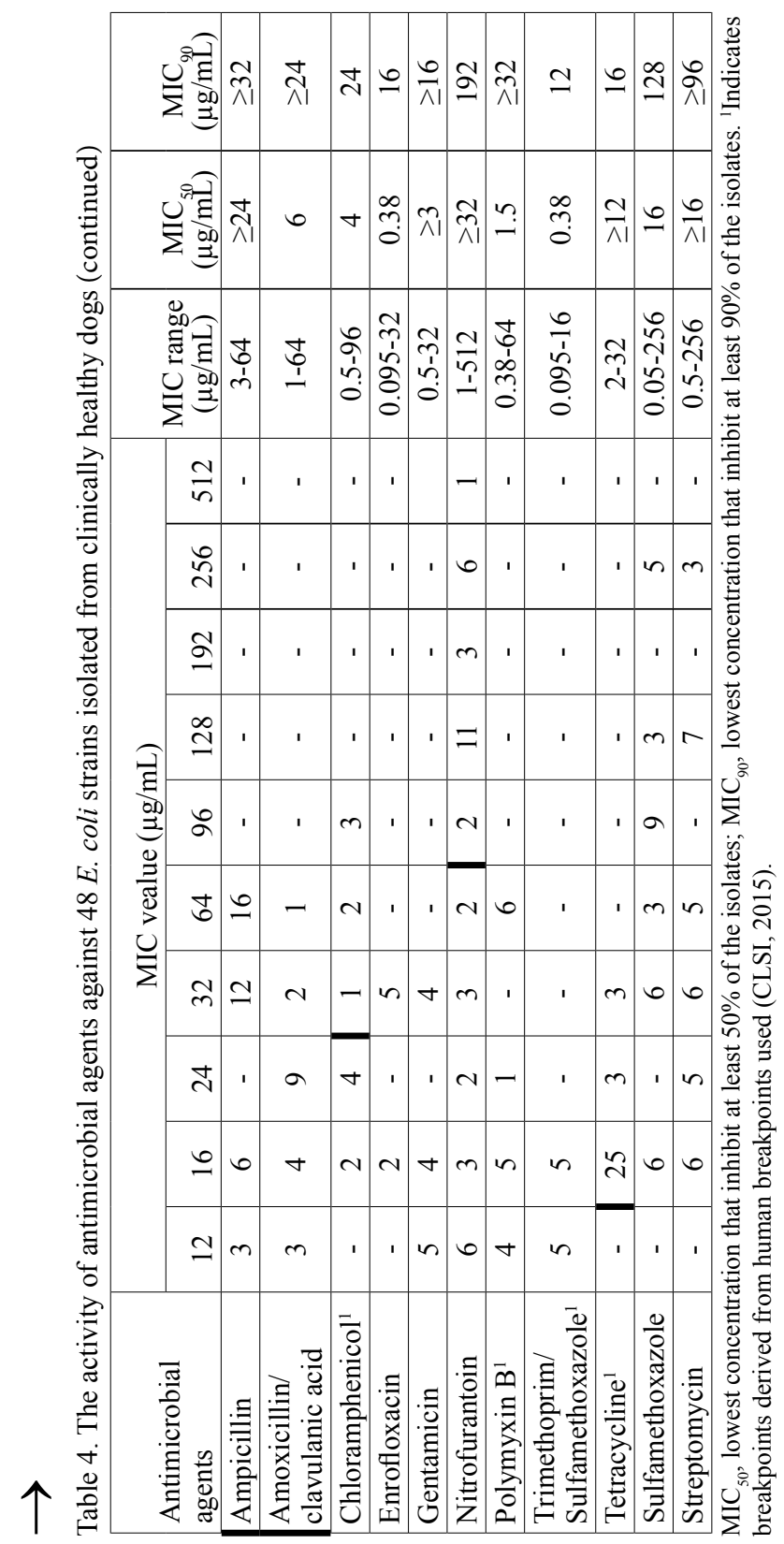




\section{J. Šiugždaitė et al.: Antimicrobial resistance of Escherichia coli}

Table 5. Antimicrobial susceptibility profiles among the $E$. coli strains isolated from different populations of dogs

\begin{tabular}{|c|c|c|c|c|c|c|}
\hline \multirow{2}{*}{$\begin{array}{l}\text { Antimicrobial } \\
\text { agents }\end{array}$} & \multirow[b]{2}{*}{ Day time location } & \multicolumn{2}{|c|}{ Resistant } & \multicolumn{2}{|c|}{ Susceptible } & \multirow[b]{2}{*}{ P-value } \\
\hline & & $\mathrm{n}$ & $\%$ & $\mathrm{n}$ & $\%$ & \\
\hline \multirow{3}{*}{$\begin{array}{l}\text { Amoxicillin/ } \\
\text { Clavulanic acid }\end{array}$} & Inside the house & 6 & 33.3 & 12 & 66.7 & \multirow{3}{*}{$\mathrm{P}>0.05$} \\
\hline & Outside & 7 & 35 & 13 & 65 & \\
\hline & Animal shelter & 6 & 60 & 4 & 40 & \\
\hline \multirow{3}{*}{ Ampicillin } & Inside the house & 13 & 72.2 & 5 & 27.8 & \multirow{3}{*}{$\mathrm{P}>0.05$} \\
\hline & Outside & 14 & 70 & 6 & 30 & \\
\hline & Animal shelter & 10 & 100 & 0 & 0 & \\
\hline \multirow{3}{*}{ Gentamicin } & Inside the house & 6 & 33.3 & 12 & 66.6 & \multirow{3}{*}{$\mathrm{P}<0.01$} \\
\hline & Outside & 5 & 25 & 15 & 75 & \\
\hline & Animal shelter & 9 & 90 & 1 & 10 & \\
\hline \multirow{3}{*}{ Enrofloxacin } & Inside the house & 7 & 38.9 & 11 & 61.2 & \multirow{3}{*}{$\mathrm{P}<0.01$} \\
\hline & Outside & 1 & 5 & 19 & 95 & \\
\hline & Animal shelter & 5 & 50 & 5 & 50 & \\
\hline \multirow{3}{*}{ Nitrofurantoin } & Inside the house & 8 & 44.4 & 10 & 55.6 & \multirow{3}{*}{$\mathrm{P}>0.05$} \\
\hline & Outside & 8 & 40 & 12 & 60 & \\
\hline & Animal shelter & 7 & 70 & 3 & 30 & \\
\hline \multirow{3}{*}{ Chloramphenicol } & Inside the house & 0 & 0 & 18 & 100 & \multirow{3}{*}{$\mathrm{P}<0.05$} \\
\hline & Outside & 2 & 10 & 18 & 90 & \\
\hline & Animal shelter & 4 & 40 & 6 & 60 & \\
\hline \multirow{3}{*}{ Streptomycin } & Inside the house & 15 & 83 & 3 & 16.7 & \multirow{3}{*}{$\mathrm{P}>0.05$} \\
\hline & Outside & 16 & 80 & 4 & 20 & \\
\hline & Animal shelter & 10 & 100 & 0 & 0 & \\
\hline \multirow{3}{*}{ Polymyxin B } & Inside the house & 5 & 27.8 & 13 & 72.2 & \multirow{3}{*}{$\mathrm{P}<0.001$} \\
\hline & Outside & 5 & 25 & 15 & 75 & \\
\hline & Animal shelter & 10 & 100 & 0 & 0 & \\
\hline \multirow{3}{*}{ Sulfamethoxazole } & Inside the house & 13 & 72.2 & 5 & 25.7 & \multirow{3}{*}{$\mathrm{P}>0.05$} \\
\hline & Outside & 13 & 65 & 7 & 35 & \\
\hline & Animal shelter & 8 & 80 & 2 & 20 & \\
\hline \multirow{3}{*}{$\begin{array}{l}\text { Trimethoprim/ } \\
\text { Sulfamethoxazole }\end{array}$} & Inside the house & 8 & 44.4 & 10 & 55.6 & \multirow{3}{*}{$\mathrm{P}>0.05$} \\
\hline & Outside & 5 & 25 & 15 & 75 & \\
\hline & Animal shelter & 5 & 50 & 5 & 50 & \\
\hline \multirow{3}{*}{ Tetracycline } & Inside the house & 11 & 61.1 & 7 & 38.9 & \multirow{3}{*}{$\mathrm{P}>0.05$} \\
\hline & Outside & 11 & 55 & 9 & 45 & \\
\hline & Animal shelter & 9 & 90 & 1 & 10 & \\
\hline
\end{tabular}

$\mathrm{P}$-value considered statistically significant at $\mathrm{P}<0.001, \mathrm{P}<0.01$ and $\mathrm{P}<0.05$. 


\section{Discussion}

Resistance of commensal E. coli to many frequently used antimicrobials is a global problem in the chemotherapy of common bacterial diseases, including pyoderma, ear and wound infections, gastroenteritis and urinary tract infections (PEDERSEN et al., 2007). Members of most classes of antimicrobials, such as tetracyclines, macrolides, lincosamides, chloramphenicols, aminoglycosides, penicillins and cephalosporins, have been used for long periods in both human and veterinary medicine, and the corresponding resistance genes have been identified in bacteria from humans and pet animals. The occurrence of the same resistance gene in bacteria from different sources suggests the transfer of the resistance gene (GUARDABASSI et al., 2004).

A high percentage was detected of resistance of the faecal E. coli isolated from clinically healthy dogs to tetracycline, sulfamethoxazole, ampicillin, and streptomycin (64.6-85.1\%). This is not surprising as these antimicrobial agents are antimicrobials commonly used in small animal veterinary practices in Lithuania. Similar resistance rates to these antimicrobial agents have been reported for $E$. coli isolates from pets, and foodproducing animals in Ireland (KARCZMARCZYK et al., 2011), as well for isolates from clinically healthy and diarrheic pets in Brazil (PAULA et al., 2008). High percentages of resistance to streptomycin (96.4\%), tetracycline (53\%) and aminopenicillins $(70.2 \%)$ have been reported for $E$. coli isolated from diseased dogs and cats in Poland (RZEWUSKA et al., 2015). Resistance to similar antimicrobial agents was reported for $E$. coli isolated from clinical specimens from humans and food animals in the United States. E. coli isolates from humans were most often resistant to sulphonamide (19.9\%), followed by tetracycline $(18 \%)$ and ampicillin $(16.5 \%)$. High resistance rates to tetracycline (71.1\%), streptomycin (59\%), sulphonamide (57.7\%), and to ampicillin $(34.1 \%)$ have been recorded for $E$. coli isolates from animal sources (TADESSE et al., 2012). The explanation of the high level of resistance among $E$. coli isolates to these antimicrobial agents may be the widespread use of broad-spectrum antimicrobials. Ampicillin is often used as a first-line antibiotic for empirical treatment of bacterial diseases in animals. Other generally effective antibiotics used empirically for prophylaxis and treatment are potentiated sulphonamides, tetracycline, chloramphenicol or cephalosporins. These are bacteriostatic agents, which generally demonstrate good efficacy against Gram-positive and/or negative bacteria (TADESSE et al., 2012; CHANG et al., 2015).

In the present study, a moderate level (37.5-41.7\%) of resistance was identified of faecal $E$. coli isolates from healthy dogs to amoxicillin/clavulanic acid, gentamicin and trimethoprim/sulfamethoxazole, but it was higher than the rates reported $(2-3 \%)$ in Canada (MURPHY et al., 2009) or (7.3-25.2\%) in Denmark (PEDERSEN et al., 2007). In the United States, low percentages of resistance (9.1-15.6\%) to amoxicillin/clavulanic acid, gentamicin and trimethoprim/sulfamethoxazole have been detected for $E$. coli 
isolated from humans (0.1-2.4\%) and food producing animals (TADESSE et al., 2012). An increase in resistance to these antimicrobial agents was determined in $E$. coli isolates from humans in Switzerland (BLAETTLER et al., 2009). Common use of antimicrobials may explain the rather high resistance rates for amoxicillin/clavulanic acid, gentamicin and trimethoprim/sulfamethoxazole. The results indicate that these antimicrobial agents should be used only if the susceptibility of the bacteria is confirmed by in vitro study.

In this study, E. coli isolated from healthy pets showed a moderate level $(47.9 \%$ $41.7 \%$ ) of resistance to nitrofurantoin and polymyxin B. In small animal practice, the use of nitrofurantoin has been gradually abandoned due to its higher toxicity and lower pharmacokinetic performance (MAALAND and GUARDABASSI, 2011). The increased level of resistance to nitrofurantoin may be explained by the fact that in veterinary clinical practice the use of nitrofurantoin may be indicated for treatment of urinary tract infection caused by multidrug-resistant $E$. coli bacteria or methicillin-resistant staphylococcus, which are otherwise difficult to treat using conventional veterinary antimicrobial products (GUAY, 2001). The same experience of using these antimicrobials is applied in Lithuanian small animal veterinary clinics. The use of polymyxin $s$ is similar to nitrofurantoin, and these polycationic antimicrobial peptides are currently the last-resort antibiotics for treatment of infection caused by multidrug-resistant Gram-negative bacteria (FALAGAS et al., 2005). The possibility that polymyxin -resistant, community-acquired strains exist increases the challenge of treating patients with infections caused by such organisms. It is important to mention that $37.5 \%$ of our isolated E. coli strains showed multi-drug resistance (MDR). MDR bacteria have been isolated from many animal species, including pigs, cattle, chickens, turkeys, dogs, cats, rodents (HO et al., 2011; CUNHA et al., 2014; RZEWUSKA et al., 2015) and humans (BAILEY et al., 2010). In companion animals, a moderate level of multi-drug resistance of $E$. coli has been found: $28.9 \%$ in the United States (SHAHEEN et al., 2010), and $43.3 \%$ in Japan (HO et al., 2010). Our findings suggest that inadequate selection and use of antimicrobials may lead to antimicrobial resistance in these bacteria, and make the treatment of bacterial infections more difficult.

A low percentage of $E$. coli isolates resistant to enrofloxacin and chloramphenicol was found in the present study. Fluorquinolones are available for treatment of companion animals and humans in many European countries (BLAETTLER et al., 2009; RZEWUSKA et al., 2015). Over the years, the prevalence of fluorquinolone resistance has increased in bacteria isolated both from human patients and animals (BLAETTLER et al., 2009; GIBSON et al., 2010). The chloramphenicol resistance level found in this study was higher than those reported from healthy dogs in Denmark (0.6-3.9\%) and Canada (0.5-5\%) (PEDERSEN et al., 2007; MURPHY et al., 2009). However, in this study, enrofloxacin and chloramphenicol demonstrated a low level of in vitro resistance, which suggests that they may be used as adequate alternative therapy for animal infections, if other appropriate antimicrobial agents are not effective. 
Tetracycline resistance in the $E$. coli isolates described in this study was associated with tetA $(6.4 \%)$ and tet $\mathrm{B}(3.2 \%)$ genes. The most common resistance mechanism found in Gram-negative bacteria obtained from humans (WILKERSON et al., 2004) and animals (WILKERSON et al., 2004; COSTA et al., 2008; AHMED et al., 2010) is the energy-dependent efflux pump system (efflux genes), encoded by tet $A$, tet $B, \operatorname{tet} C$, tet $D$, and $t e t G$, with tet $A$ and tet $B$ genes being the most frequently described. Efflux genes are normally associated with large plasmids, which often carry other antibiotics resistance genes, heavy metal resistance genes, and/or other pathogenic factors, such as toxins (DIARRASSOUBA et al., 2007; OLOWE et al., 2013). Ribosomal protection mechanisms are more common among Gram-positive bacteria (OLOWE et al., 2013). The results of our study suggest the possibility that $E$. coli from companion animals may be a reservoir for tetracycline resistance. Regarding other isolates which were phenotypically resistant against tetracycline, and did not carry tet $A$ or $\operatorname{tet} B$ genes, the resistance was most likely due to the presence of other tetracycline resistance genes eg., tetE or tetD (OLOWE et al., 2013).

A small number $(5.5 \%)$ of trimethoprim/sulfamethoxazole-resistant isolates were positive to the $d f r A l$ in the present study. Epidemiological studies indicate that the $d f r A l$ gene is very common among trimethoprim-resistant $E$. coli isolates of animal and human origin (COSTA et al., 2008; AHMED et al., 2010). It has been proven that the $d f r A 1$ gene spreads rapidly on the transposon $\operatorname{Tn} 7$ and is the most prevalent gene responsible for trimethoprim resistance in E. coli isolates (TOWNER et al., 1994; COSTA et al., 2008; AHMED et al., 2010). We suppose that other E. coli isolates which do not carry the $d f r A$ lgene, may be resistant to trimethoprim through the prevalence of $d f r A 14, d f r A 7$, dfrA1, dfrA8, dfrA13, dfrA5, dfrA12, dfrA 9 or $d$ frA 17 genes (LEE et al., 2001; KANG et al., 2005; AHMED et al., 2010). A low percentage (16.1\%) of catAl gene encoding the synthesis of chloramphenicol acetyltransferase and the absence of the $\mathrm{cmlA}$ gene was found in the chloramphenicol resistant $E$. coli isolates in the present study. However, the small number of the catAl gene identified by PCR suggests that the observed chloramphenicol resistance was possibly present due to the different types of cat genes (NG et al., 2014). No beta-lactam resistance encoded genes $\left(b l a_{\mathrm{SHV}}\right.$ and $\left.b l a_{\mathrm{CMY}}\right)$ were detected in the ampicillin and amoxicillin/clavulanic acid resistant $E$. coli isolates in this study. There are several hundred types of beta-lactamase enzymes, encoded by different types of bla (beta-lactamase) genes. Several studies have reported that TEM betalactamase genes (i.e. TEM-1 beta-lactamase gene) are the most prevalent in ampicillin resistant $E$. coli of animal origin, as well as being commonly reported in human $E$. coli isolates of hospital origin (AHMED et al., 2010). Additional investigation of the TEM-1 genes may be necessary to identify the mechanism leading the resistance against betalactamic antimicrobials. 


\section{J. Šiugždaitė et al.: Antimicrobial resistance of Escherichia coli}

E. coli resistance to gentamicin is most commonly mediated by aacC2, aac(3)-I, aac(3)-II, aac(3)-IV, ant(2)-I and aadB genes. The increasing frequency of genes encoding these enzymes in clinical isolates of human and animal origin has been reported by $\mathrm{HO}$ et al. (2010), KARCZMARCZYK et al. (2011), SOLEIMANI et al. (2014) and CHANG et al. (2015). No $a a c(3)-I V$ and $a a d A$ genes in gentamicin-resistant $E$. coli isolates were identified by multiplex PCR in the present study. We were not able to identify resistance to quinolones and sulphanilamides with qnrA and sull genes. Therefore, further characterization of the mechanisms of resistance to those antimicrobial agents is needed.

The prevalence of antimicrobial resistance for the $E$. coli isolates from the shelter dog population was significantly higher than for isolates from populations of outdoor and indoor dogs. Several studies (GINGRICH et al., 2011; PROCTER et al., 2014) showed that animals in the shelter environment may be at increased risk of becoming colonized or diseased with a variety of infectious agents. These dogs may serve as reservoirs of resistant strains of bacteria for several reasons, including high animal density, the potential for nosocomial spread by staff members and volunteers, suboptimal cleaning and disinfectant routines, the unknown pathogen carriage status of the majority of animals, widespread use of antibiotics, and stress from the environment. DE GRAEF et al. (2004) reported that multi-drug resistance was more frequent in breeding kennel dogs than in individually owned dogs. These findings support the notion that close contact between dogs, whether living together or staying together for a large part of the day, may increase the likelihood of sharing antimicrobial resistant bacteria and resistance genes (PROCTER et al., 2014).

Our study may be influenced by the consequences of a previous study. In 2010, veterinarians from small animal clinics in city $\mathrm{X}$ were asked for information on the most commonly used antimicrobials for the treatment of Gram negative bacterial infections, including E. coli. According to the veterinarians' answers the most frequency used antimicrobial materials were selected for this study. At present, the use of antimicrobial agents is changing, and veterinarians often choose cephalosporins since the prevalence of antimicrobial resistance is increasing. In a future study, it is necessary to investigate the resistance of commensal flora to different generations of cephalosporins.

In conclusion, clinically healthy dogs are important reservoirs of antimicrobial resistance to commensal bacteria. A commensal strain may later cause infection in the same or another host, or transfer its resistance genes to other bacteria. To our knowledge, this is the first study in our country which has investigated the prevalence and antimicrobial resistant patterns of commensal E. coli strains in healthy dogs. Therefore, the findings of this study indicate that companion animals in Lithuania are important reservoirs of antimicrobial resistance to commensal bacterial strains, and deserve more detailed studies. 


\section{J. Šiugždaitė et al.: Antimicrobial resistance of Escherichia coli}

\section{Acknowledgements}

This study was supported by Project Cost ES 1403 Action - „New and emerging challenges and opportunities in wastewater reuse (Nereus)“.

\section{Reference}

AHMED, M. O., P. D. CLEGG, N. J. WILLIAMS, K. E. BAPTISTE, M. BENNETT (2010): Antimicrobial resistance in equine faecal Escherichia coli isolates from North West England. Ann. Clin. Microbiol. Antimicrob. 9, 12.

BAILEY, K. J., J. L. PINYON, S. ANANTHAM, R. M. HALL (2010): Commensal Escherichia coli of healthy humans: a reservoir for antibiotic-resistance determinants. J. Med. Microbiol. 59, 1331-1339.

BLAETTLER, L., D. MERTZ, R. FREI, L. ELZI, A. F. WIDMER, M. BATTEGAY, U. FLUCKIGER (2009): Secular trend and risk factors for antimicrobial resistance in Escherichia coli isolates in Switzerland 1997-2007. Infection. 37, 534-539.

BOUROUNI, O. C., M. EL BOU, P. COLA-MATA, J. BARROS-VALA'ZQUEZ (2012): Antimicrobial resistance and potential probiotic application of Enterococcus spp. in sea Bass and sea Bream aquaculture. In: Antibiotic resistant bacteria - a continuous challenge in the new millennium. (PANA, M. Ed.), ISBN: 978-953-51-0472-8, In Tech, pp. 19.

CHANG, S. K., D. Y. LO, H. W. WEI, H. C. KUO (2015): Antimicrobial resistance of Escherichia coli isolates from canine urinary tract infections. J. Vet. Med. Sci. 77, 59-65.

CLSI (2015): Performance standards for antimicrobial susceptibility testing. M100. $27^{\text {th }}$ ed. USA. pp. 248.

COSTA, D., P. POETA, Y. SÁENZ, A. C. COELHO, M. MATOS, L. VINUÉ, J. RODRIGUES, C. TORRES (2008): Prevalence of antimicrobial resistance and resistance genes in faecal Escherichia coli isolates recovered from healthy pets. Vet. Microbiol. 127, 97-105.

CUNHA, M. P. V., M. G. DE OLIVEIRA, M. C. DE OLIVEIRA, K. C. DA SILVA, C. R. GOMES, A. M. MORENO, T. KNÖBL (2014): Virulence profiles, phylogenetic background, and antibiotic resistance of Escherichia coli isolated from turkeys with airsacculitis. Sci. World J. $1-8$.

DAMBORG, P., E. M. BROENS, B. B. CHOMEL, S. GUENTHER, F. PASMANS, J. A. WAGENAAR, J. S. WEESE, L. H. WIELER, U. WINDAHL, D. VANROMPAY, L. GUARDABASSI (2016): Bacterial zoonosis transmitted by household pets: state-of-the-art and future perspectives for targeted research and policy actions. J. Comp. Path. 155, S27-S40.

DE GRAEF, E. M., A. DECOSTERE, L. A. DEVRIESE, F. HAESEBROUCK (2004): Antibiotic resistance among faecal indicator bacteria from healthy individually owned and kennel dogs. Microb. Drug Resist. 10, 65-69. 
DIARRASSOUBA, F., M. S. DIARRA, S. BACH, P. DELAQUIS, J. PRITCHARD, E. TOPP, J. B. SKURA (2007): Antibiotic resistance and virulence genes in commensal Escherichia coli and Salmonella isolates from commercial broiler chicken farms. J. Food Prot. 70, 1316-1327.

EUCAST (2017): The European committee on antimicrobial susceptibility testing. breakpoint tables for interpretation of MICs and zone diameters. Version 7.0. http://www.eucast.org.

FALAGAS, M. E., S. K. KASIAKOU, L. D. SARAVOLATZ (2005): Colistin: the revival of polymyxins for the management of multidrug-resistant gram-negative bacterial infections. Clin. Infect. Dis. 40, 1333-1341.

GHOSH, P., A. MAHANTI, I. SAMANTA, S. N. JOARDAR, K. BATABYAL, S. DEY, S. TARAPHDER, D. P. ISORE (2017): Occurrence of extended-spectrum cephalosporinase producing Escherichia coli in kuroiler birds. Vet. arhiv 87, 745-757.

GIBSON, J. S., R. N. COBBOLD, M. T. KYAW-TANNER, P. HEISIG, D. J. TROTT (2010): Fluoroquinolone resistance mechanisms in multidrug-resistant Escherichia coli isolated from extraintestinal infections in dogs. Vet. Microbiol. 146, 161-166.

GINGRICH, E. N., T. KURT, D. R. HYATT, M. R. LAPPIN, R. RUCH-GALLIE (2011): Prevalence of methicillin-resistant staphylococci in northern Colorado shelter animals. J. Vet. Diagn. Invest. 23, 947-950.

GUARDABASSI, L., S. SCHWARZ, D. H. LLOYD (2004): Pet animals as reservoirs of antimicrobial-resistant bacteria. J. Antimicrob. Chemother. 54, 321-332.

GUAY, D. R (2001): An update on the role of nitrofurans in the management of urinary tract infections. Drugs 61, 353-364.

HO, P. L., K. H. CHOW, E. L. LAI, W. U. LO, M. K. YEUNG, J. CHAN, P. Y. CHAN, Y. YUEN (2011): Extensive dissemination of CTX-M-producing Escherichia coli with multidrug resistance to "critically important" antibiotics among food animals in Hong Kong, 2008-10. J. Antimicrob. Chemother. 66, 765-768.

HO, P. L., R. C. WONG, S. W. LO, K. H. CHOW, S. S. WONG, T. L. QUE (2010): Genetic identity of aminoglycoside-resistance genes in Escherichia coli isolates from human and animal sources. J. Med. Microbiol. 59, 702-707.

KANG, H. Y., S. Y. JEONG, J. Y. OH, S. H. TAE, C. H. CHOI, D. C. MOON, W. K. LEE, Y. C. LEE, S. Y. SEOL, D. T. CHO, J. C. LEE (2005): Characterization of antimicrobial resistance and class 1 integrons found in Escherichia coli isolates from humans and animals in Korea. J. Antimicrob. Chemother. 55, 639-644.

KARCZMARCZYK, M., Y. ABBOTT, C. WALSH, N. LEONARD, S. FANNING (2011): Characterization of multidrug-resistant Escherichia coli isolates from animals presenting at a university veterinary hospital. Appl. Environ. Microbiol. 77, 7104-7112.

LEE, J. C., J. Y. OH, J. W. CHO, J. C. PARK, J. M. KIM, S. Y. SEOL, D. T. CHO (2001): The prevalence of trimethoprim-resistance-conferring dihydrolate reductase genes in urinary isolates of Escherichia coli in Korea. J. Antimicrob. Chemother. 47, 599-604.

LEONARD, E. K., D. L. PEARL, R. L. FINLEY, N. JANECKO, R. J. REID-SMITH, A. S. PEREGRINE, J. S. WEESE (2012): Comparison of antimicrobial resistance patterns of 


\section{J. Šiugždaitė et al.: Antimicrobial resistance of Escherichia coli}

Salmonella spp. and Escherichia coli recovered from pet dogs from volunteer households in Ontario (2005-06). J. Antimicrob. Chemother. 67, 174-181.

MAALAND, M., L. GUARDABASSI (2011): In vitro antimicrobial activity of nitrofurantoin against Escherichia coli and Staphylococcus pseudintermedius isolated from dogs and cats. Vet. Microbiol. 151, 396-399.

MAMMERI, H., M. VAN DE LOO, L. POIREL, L. MARTINEZ-MARTINEZ, P. NORDMANN (2005): Emergence of plasmid-mediated quinolone resistance in Escherichia coli in Europe. Antimicrob. Agents Chemother. 49, 71-76.

MOMTAZ, H., E. RAHIMI, S. MOSHKELANI (2012): Molecular detection of antimicrobial resistance genes in E. coli isolated from slaughtered commercial chickens in Iran. Vet. MedCzech. 57, 193-197.

MOYAERT, H., E. M. DE GRAEF, F. HAESEBROUCK, A. DECOSTERE (2006): Acquired antimicrobial resistance in the intestinal micro biota of diverse cat populations. Res. Vet. Sci. 81, 1-7.

MURPHY, C., R. J. REID-SMITH, J. F. PRESCOTT, B. N. BONNETT, C. POPPE, P. BOERLIN, J. S. WEESE, N. JANECKO, S. A. MCEWEN (2009): Occurrence of antimicrobial resistant bacteria in healthy dogs and cats presented to private veterinary hospitals in southern Ontario: A preliminary study. Can. Vet. J. 50, 1047-1053.

NG, K. H., L. SAMUEL, M. M. KATHLEEN, S. S. LEONG, C. FELECIA (2014): Distribution and prevalence of chloramphenicol-resistance gene in Escherichia coli isolated from aquaculture and other environment. Int. Food Res. J. 21, 1321-1325.

OLOWE, O. A., O. J. IDRIS, S. S. TAIWO (2013): Prevalence of tet genes mediating tetracycline resistance in Escherichia coli clinical isolates in Osun State, Nigeria. Eur. J. Microbiol. Immunolog. 3, 135-140.

ÖSTERBERG, J., A. WINGSTRAND, A. NYGAARD JENSEN, A. KEROUANTON, V. CIBIN, L. BARCO, M. DENIS, S. AABO, B. BENGTSSON (2016): Antibiotic resistance in Escherichia coli from pigs in organic and conventional farming in four European countries. PLoS ONE. 11.

PAULA, C. J. S., A. E. STELLA, E. SANTO, F. A. ÁVILA, J. M. MARIN (2008): Antimicrobialresistance among Escherichia coli isolated from either diarrheic or healthy dogs in Ituverava, Sao Paulo State, Brazil. Ars. Veterinaria 24, 117-121.

PEDERSEN, K., K. PEDERSEN, H. JENSEN, K. FINSTER, V. F. JENSEN, O. E. HEUER (2007): Occurrence of antimicrobial resistance in bacteria from diagnostic samples from dogs. J. Antimicrob. Chemother. 60, 775-781.

Platell, J. L., R. N. COBBOLD, J. R. JOHNSON., A. HEISIG, P. HEISIG, C CLABOTS, M. A. KUSKOWSKI, D. J. TROTT (2011): Commonality among fluoroquinolone-resistant sequence type ST131 extraintestinal Escherichia coli isolates from humans and companion animals in Australia. Antimicrob. Agents Chemother. 55, 3782-3787.

POVILONIS, J., V. ŠEPUTIENĖ, M. RUŽAUSKAS, R. ŠIUGŽDINIENĖ, M. VIRGAILIS, A. PAVILONIS, E. SUŽIEDĖLIENĖ (2010): Transferable class 1 and 2 integrons in Escherichia 


\section{J. Šiugždaitė et al.: Antimicrobial resistance of Escherichia coli}

coli and Salmonella enterica isolates of human and animal origin in Lithuania. Foodborne Pathog. Dis. 7, 1185-1192.

PROCTER, T. D., D. L. PEARL, R. L. FINLEY, E. K. LEONARD, N. JANECKO, R. J. REIDSMITH, J. S. WEESE, A. S. PEREGRINE, J. M. SARGEANT (2014): A cross-sectional study examining the prevalence and risk factors for anti-microbial-resistant generic Escherichia coli in domestic dogs that frequent dog parks in three cities in south-western Ontario, Canada. Zoon. Pub. Health 61, 250-259.

RANDALL, L. P., S. W. COOLES, M. K. OSBORN, L. J. PIDDOCK, M. J. WOODWARD (2004): Antibiotic resistance genes, integrons and multiple antibiotic resistance in thirty-five serotypes of Salmonella enterica isolated from humans and animals in the UK. J. Antimicrob. Chemother. 53, 208-216.

RZEWUSKA, M., M. CZOPOWICZ, M. KIZERWETTER-UWIDA, D. CHROBAK, B. BASZCZAK, M. BINEK (2015): Multidrug resistance in Escherichia coli strains isolated from infections in dogs and cats in Poland (2007-2013). Sci. World J. 1-7.

SAWANT, A. A., N. V. HAGDE, B. A. STRAley, S. D. DONALDSON, B. C. LOVE, S. J. KNABEL, B. M. JAYARAO (2007): Antimicrobial-resistant enteric bacteria from dairy cattle. Appl. Environ. Microbiol. 73, 156-163.

SHAHEEN, B. W., D. M. BOOTHE, O. A. OYARZABAL, T. SMAHA (2010): Antimicrobial resistance profiles and clonal relatedness of canine and feline Escherichia coli pathogens expressing multidrug resistance in the United States. J. Vet. Intern. Med. 24, 323-330.

SOLEIMANI, N., M. AGANJ, L. ALI, L. SHOKOOHIZADEH, T. SAKINC (2014): Frequency distribution of genes encoding aminoglycoside modifying enzymes in uropathogenic $E$. coli isolated from Iranian hospital. BMC Res. Notes 7, 842.

ŠEPUTIENĖ, V., J. POVILONIS, M. RUŽAUSKAS, A. PAVILONIS, E. SUŽIEDĖLIENĖ (2010): Prevalence of trimethoprim resistance genes in Escherichia coli isolates of human and animal origin in Lithuania. J. Med. Microbiol. 59, 315-322.

TADESSE, D. A., S. ZHAO, E. TONG, S. AYERS, A. SINGH, M. J. BARTHOLOMEW, P. F. MCDERMOTT (2012): Antimicrobial drug resistance in Escherichia coli from humans and food animals, United States, 1950-2002. Emerg. Infec. Dis. 18, 741-749.

TAMANG, M. D., H. M. NAM, G. C. JANG, S. R. KIM, M. H. CHAE, S. C. JUNG, J. W. BYUN, Y. H. PARK, S. K. LIM (2012): Molecular characterization of extended-spectrum- $\beta$-lactamaseproducing and plasmid-mediated AmpC $\beta$-lactamase-producing Escherichia coli isolated from stray dogs in South Korea. Antimicrob. Agents Chemother. 56, 2705-2712.

TORO, C. S., M. FARFA'N, I. CONTRERAS, O. FLORES, N. NAVARRO, G. C. MORA, V. PRADO (2005): Genetic analysis of antibiotic-resistance determinants in multidrug-resistant Shigella strains isolated from Chilean children. Epidemiol. Infect. 133, 81-86.

TOWNER, K. J., A. BRENNAN, Y. ZHANG, C. A. HOLTHAM, J. L. BROUGH, G. I. CARTER (1994): Genetic structures associated with spread of the type Ia trimethoprim-resistant dihydrofolate reductase gene amongst Escherichia coli strains isolated in the Nottingham area of the United Kingdom. J. Antimicrob. Chemother. 33, 25-32. 


\section{J. Šiugždaitė et al.: Antimicrobial resistance of Escherichia coli}

VAN, T. T., J. CHIN, T. CHAPMAN, L. T. TRAN, P. J. COLOE (2008): Safety of raw meat and shellfish in Vietnam: an analysis of Escherichia coli isolations for antibiotic resistance and virulence genes. Int. J. Food Microbiol. 124, 217-223.

WILKERSON, C., M. SAMADPOUR, N. VAN KIRK, M. C. ROBERTS (2004): Antibiotic resistance and distribution of tetracycline resistance genes in Escherichia coli O157:H7 isolates from humans and bovines. Antimicrob. Agents Chemother. 48, 1066-1067.

Received: 10 January 2017

Accepted: 17 January 2018

\section{ŠIUGŽDAITE், J.,A. GABINAITIENĖ, S. KERZIENE், S.A. LAURUSEVIČIUS, T. LAURUSEVIČIUS: Antimikrobna rezistencija bakterija Escherichia coli izoliranih iz zdravih pasa u Litvi. Vet. arhiv 88, 355-373, 2018. \\ SAŽETAK}

Cilj ovoga istraživanja bio je utvrditi prevalenciju i antimikrobno rezistentne oblike komenzalne bakterije Escherichia coli, izolirane iz zdravih pasa. Za izolaciju bakterija Escherichia coli korišteno je ukupno 55 briseva rektuma zdravih pasa od kojih je jedna skupina držana na otvorenom $(n=20)$, jedna skupina u kući $(n=20)$, a jedna je skupina držana u skloništu za životinje $(n=15)$. Analiza oblika rezistencije na 11 antimikrobnih sredstava provedena je E-testom (test Epsilometar) za određivanje minimalne inhibitorne koncentracije (MIK). Multipleks reakcija lančanom polimerazom (M-PCR) upotrijebljena je za pronalaženje odabranih gena odgovornih za otpornost na beta-laktame, tetraciklin, aminoglikozid, sulfanilamid, kinolon i fenikol klase antimikrobnih sredstava. Od 55 pasa izolirano je 48 sojeva $(87,3 \%)$ E. coli. Višestruka otpornost na lijekove bila je prisutna u $38 \%$ rezistentnih izolata. Izolati $E$. coli pokazali su najveću stopu rezistencije na streptomicin $(85,1 \%)$, ampicilin $(77,1 \%)$, sulfametoksazol $(70,8 \%)$ i tetraciklin $(64,6 \%)$. Najveća osjetljivost izolata utvrđena je na enrofloksacin $(87,5 \%)$ i kloramfenikol $(72,9 \%)$. Bakterijski geni za otpornost određeni su za tetraciklin (tet) $(9,7 \%)$ trimetoprim/sulfametoksazol (dfrAl) $(16,7 \%)$ i kloramfenikol (catAl) $(5,5 \%)$. Općenito, prevalencija antimikrobne rezistencije izolata $E$. coli iz skupine pasa držanih u skloništima bila je veća nego kod pasa držanih u kući ili na otvorenom $(\mathrm{P}<0,05)$. U Litvi su životinje za druženje važan rezervoar rezistentnih sojeva bakterije Escherichia coli. Samo prikladna uporaba antimikrobnih lijekova može smanjiti šrenje otpornih bakterija između zdravih i bolesnih životinja odnosno ljudi.

Ključne riječi: antimikrobna rezistencija; komenzalna Escherichia coli; zdravi psi 
